\title{
Carrier Cultures of Human Fetal Diploid Cells Infected with Coxsackievirus Type B $2^{1}$
}

\author{
By \\ N. H. Maverakis², Nathalie J. Schmidt, J. L. Riggs, and E. H. Lennette \\ Viral and Rickettsial Disease Laboratory, \\ California State Department of Public Health, \\ Berkeley, U.S.A.
}

With 1 Figure

Received March 2, 1973

\begin{abstract}
Summary
Carrier cultures of coxsackievirus type B2, strain V1-013 were established without the use of "normal" human serum or serum containing viral antibodies, and without frequent changes of medium. Blind passage of virus strain V1-013 in human fetal diploid (HFD) cell cultures on maintenance medium resulted in viral multiplication without apparent CPE. In addition, human fetal diploid cultures infected with the V1-013 virus strain could be subcultivated for over 20 transfers, and infectious virus and antigen demonstrable by immunofluorescent staining were present at each passage level; again, viral multiplication occurred without apparent CPE. Sustained infections were not observed when HFD cells were inoculated with two other (Ohio and Lincoln) B2 coxsackievirus strains; however, the life-span of inoculated cultures was reduced in comparison to that of control cultures.
\end{abstract}

\section{Introduction}

The term "carrier culture" is synonymous with "carrier strain". The former designates a virus-infected culture of animal cells, while the latter applies to a phage-infected culture of bacterial cells (10). Both signify a more or less stable state of equilibrium between host cells and virus. Carrier cultures show no apparent cytopathic effect (CPE) but infectious virus may be recovered during each subcultivation. This is in contrast to cultures harboring latent viruses, in which infectious virus is not detectable, but may then appear, either spontaneously or as a result of physical or chemical treatment. In most systems investigated, carrier cultures can eventually be cured of virus by exposure to high concentrations of

1 These studies were supported by Public Health Service Grants GM 01038-10 from the National Institute of General Medical Sciences and AI-01475 from the National Institute of Allergy and Infectious Diseases.

2 Present address: Department of Epidemiology, School of Public Health, University of Michigan, Ann Arbor, MI 48104, U.S.A. 
specific viral antibodies. The following four types of carrier cultures have been described $(23)$, a) infections in cultures of predominantly resistant cells with a minority of susceptible cells, b) infections in cultures of susceptible cells protected by antibody or by balancing virus production and virus elimination, c) infections in cultures of susceptible cells protected by interference and/or interferon, and d) regulated infections of cells in culture.

Early reports suggested that human serum containing viral antibodies was necessary for the maintenance of poliovirus carrier cultures of HeLa cells $(2,3,4)$. Later, cultures of poliovirus were propagated in the absence of antibody by daily washing and addition of fresh medium to the monolayers (13). With HeLa cell carrier cultures of type A9 coxsackievirus, 10 per cent human serum (lacking detectable neutralizing antibodies) was required in the outgrowth medium (20). When the serum concentration was reduced to 2 per cent, or when calf or horse serum was substituted for human serum, cellular degeneration occurred. The A9 coxsackievirus isolated from these cultures exhibited increased virulence for HeLa cells, slower plaque formation for monkey kidney cells and altered antigenic properties. It was later shown that HeLa cell carrier cultures of coxsackievirus types B3 or B 5 required human serum containing some specific viral antibody in the growth medium $(6,7)$. Addition of hyperimmune monkey serum to coxsackievirus type B5 carrier cultures resulted in elimination of the virus (7).

This report presents data to show that carrier cultures of coxsackievirus type B2 can be established in human fetal diploid kidney cells without the use of "normal" human serum or serum containing viral antibodies, and without daily washing or adding fresh medium to the cell monolayers.

\section{Materials and Methods}

\subsection{Virus Strains}

Three strains of coxsackievirus type B 2 (Ohio, Lincoln and V 1-013) were used in this study. The prototype, Ohio strain, had been passed 5 times in suckling mice $\left(\mathbf{M}_{5}\right)$ and 3 times in rhesus monkey kidney cell culture $\left(\mathrm{MK}_{3}\right)$. The field strain, Lincoln, was isolated from a stool specimen and identified in this laboratory. For the present studies the Lincoln strain was reisolated from the original stool specimen in the BS-C-1 line of grivet monkey kidney cells and, therefore, had never been passed in mice or primary monkey kidney cells. Strain V 1-013 was received from the Center for Disease Control $(C D C)$ as a proficiency test specimen and identified in this laboratory and at CDC as a type B 2 coxsackievirus. Strain V 1-013 had been passed 8 times in primary MK at CDC and once in MK in this laboratory. Each of the 3 viruses was purified by 3 terminal dilution passages in BS-C-1 cells.

\subsection{Cell Cultures}

Human fetal diploid kidney cell strains (HFDK) were established as previously described $(16,19)$. The outgrowth medium was "fortified" Eagle's minimum essential medium (MEM), prepared in Earle's balanced salt solution, supplemented with 10 per cent fetal bovine serum. When cultures had grown for 2 days, additional L-glutamine $(0.05 \mathrm{mM} / 40 \mathrm{ml}$ of fortified Eagle's MEM) was added and the medium was neutralized with sodium bicarbonate. For subpassage, cells were trypsinized and split 2 for 1 . Maintenance medium consisted of Eagle's MEM or Eagle's MEM with galactose (5.55 mm/l) substituted for glucose. The medium was supplemented with 2 per cent fetal bovine serum. Samples of every fifth passage were examined for possible contamination with mycoplasma (14). 
Cultivation of rhesus MK cells and the BS-C-1 line of grivet monkey kidney cells was done as described elsewhere (16).

\subsection{Neutralization Tests}

Tube neutralization (TN) and metabolic inhibition (MI) tests were performed as described elsewhere $(12,16,18)$. Type-specific hamster antiserum to coxseckievirus type B 2 was employed for identification tests.

\subsection{Assays for Infections Virus}

Infected HFDK cultures were frozen and thawed 3 times, then clarified by lowspeed centrifugation. The supernatant fluid was stored at $-70^{\circ} \mathrm{C}$. Ten-fold dilutions of the material were inoculated into BS-C-1 cells to test for infectious virus; cultures were observed for 11 days to detect any cytopathic effect (CPE).

\subsection{Indirect Fluorescent Antibody Test}

The procedure of RxGGS, LoH and EveLAND (15) was used for fractionation and labeling of antiserum. Ammonium sulfate precipitated goat antihamster globulin was conjugated and subjected to DEAE column chromatography (15). The recovered globulin was lyophilized in $1 \mathrm{ml}$ amounts. The molar fluorescein protein ratio $(\mathrm{F} / \mathrm{P})$ of the reconstituted conjugate was 1.8 (21). Immunoelectrophoresis of the conjugate showed a single, weakly migrating band in the globulin region.

Infected and control HFDK cells were grown on $15 \mathrm{~mm}$ round coverslips until a confluent monolayer was formed. The coverslips were rinsed 3 times in PBS ( $\mathrm{pH} 7.2$ ) and once in distilled water, fixed for 10 minutes in acetone, air-dried, and stored at $-70^{\circ} \mathrm{C}$. For the indirect fluorescent antibody test, hamster antiserum to coxsackievirus type $\mathrm{B} 2$ at dilutions of $1: 256,1: 512$, and $1: 1024$ was added to the coverslips. The reaction was allowed to proceed for 30 minutes at $37^{\circ} \mathrm{C}$ and then for 24 hours at $4^{\circ} \mathrm{C}$. The following day, after the washing procedure, the fluorescein conjugated antihamster globulin diluted 1:20 was applied and tests were incubated for 30 minutes at $37^{\circ} \mathrm{C}$. The coverslips were then washed 3 times and mounted in Elvanol. Slides were examined using a Carl Zeiss GFL standard microscope equipped with an FITC interference filter ( $400-495 \mathrm{~nm}$ range) and a 50 barrier filter $(515 \mathrm{~nm}$ range). Tllumination was provided by a halogen lamp $(12 \mathrm{~V}-100 \mathrm{~W})$.

\subsection{Plaque Assay}

BS-C-1 cells were grown in $35 \times 10 \mathrm{~mm}$ plastic Petri dishes (Falcon No. 3001 plates). Each dish received $3 \mathrm{ml}$ of cells $\left(4 \times 10^{5}\right.$ cells/ml) suspended in medium 199 prepared in Hanks' balanced salt solution (HBSS) and containing 10 per cent fetal bovine serum. Plates were incubated in a humidified 5 per cent $\mathrm{CO}_{2}$ atmosphere at $37^{\circ} \mathrm{C}$ for $3-5$ days. Confluent monolayers were washed with HBSS, infected with $0.1 \mathrm{ml}$ of the diluted virus suspension, incubated for $1 \frac{1}{2}$ hours and overlayed with $2.5 \mathrm{ml}$ of nutrient agar overlay consisting of 1.4 per cent Ionagar No. 2 or of 2 per cent agarose mixed with double strength maintenance medium containing 10 per cent FBS. A second nutrient agar overlay $(1 \mathrm{ml})$, containing neutral red at a concentration of $1: 5,000$ per ml was added 8 days after the first. The plates were incubated overnight and plaque diameters were measured the next morning.

\section{Results}

\subsection{Cytopathic Effect of Coxsackievirus Type B2 in HFDK and BS-C-1 Cells}

As previously reported, different strains of an enterovirus immunotype may vary in their ability to replicate in various host systems (5). Therefore, three strains of coxsackievirus type B2 were examined to see if they differed demonstrably in their ability to replicate in HFDK and BS-C-1 cells. These were the prototype Ohio strain, a field strain (Lincoln) and the V1-013 strain from CDC. Tube cultures of each cell type (maintained on MEM containing galactose and 2 per cent FBS) 
were inoculated with 1,000 TCID $_{50}$ of virus per tube. Eight tubes were used for each strain and cultures were examined under low-power magnification over a period. of 14 days. Uninoculated cultures of the same cell types served as controls. None of the strains produced an overt CPE in HFDK cells, but all three produced a 4 plus CPE by 6 days in BS-C-1 cells. Other reports $(17,22)$ have indicated that human diploid cell strains are relatively insensitive for isolation of group B coxsackieviruses but in human primary embryo kidney cells, coxsackievirus type B2 produced CPE between 7-24 days (11). The difference in susceptibility between HFDK cells used in our study and that reported for primary human embryonic kidney cells may be associated with the fact that diploid cells strains at the passage level used in the present study are fibroblastic while primary embryonic kidney cells are epithelial.

\subsection{Replication of Type B2 Coxsackievirus Strain V1.013 in HFDK Cells}

Studies were conducted to determine whether viral replication might occur in HFDK cells in the absence of an overt cytopathic effect.

Blind passages were made at weekly intervals of the V1-013 virus strain in HFDK cells. This consisted of the serial transfer of inoculated HFDK cells and fluids from tube cultures showing no CPE into fresh tubes of HFDK cells. $\log _{10}$ dilutions of suspended cells from each HFDK passage level were inoculated in parallel into HFDK and MK tube cultures. For subpassage, the HFDK cultures which had been inoculated with the highest dilution producing CPE in MK cells were harvested and further diluted for subsequent passage into tube cultures of HFDK and MK cells. This was done for a total of 6 passages. In Table 1, it is seen

Table 1. Blind Passage of Type B2 Coxsackievirus Strain V1-013 in HFDK Cells

\begin{tabular}{|c|c|c|c|}
\hline $\begin{array}{l}\text { Virus passage } \\
\text { history }\end{array}$ & $\begin{array}{l}\text { CPE in } \\
\text { HFDK } \\
\text { cells }\end{array}$ & $\begin{array}{l}\text { Virus titer of } \\
\text { HFDK material } \\
\text { (TCID } 50 \text { per ml) }^{2}\end{array}$ & $\begin{array}{l}\text { Time of occurrence of } 4 \text { plus CPE } \\
\text { in MK cells inoculated with HFDK } \\
\text { material endpoint dilution }\end{array}$ \\
\hline $\mathrm{MK}_{9}, \mathrm{HFDK}_{1} \mathrm{~b}$ & 0 & $10^{-4.0}$ & 7 days \\
\hline $\mathrm{MK}_{9}, \mathrm{HFDK}_{2} \mathrm{~b}$ & 0 & $10^{-4.0}$ & 7 days \\
\hline $\mathrm{MK}_{9}, \mathrm{HFDK}_{3} \mathrm{~b}$ & 0 & $10^{-3.5}$ & 5 days \\
\hline $\mathrm{MK}_{9}, \mathrm{HFDK}_{4} \mathrm{~b}$ & 0 & $10^{-4.0}$ & 7 days \\
\hline $\mathrm{MK}_{9}, \mathrm{HFDK}_{5} \mathrm{~b}$ & 0 & $10^{-3.0}$ & 7 days \\
\hline $\mathrm{MK}_{9}, \mathrm{HFDK}_{6}$ & 0 & $10^{-3.0}$ & 6 days \\
\hline
\end{tabular}

a HFDK material (cells and fluids frozen and thawed 3 times) was titrated in primary monkey kidney cells.

b Highest dilution of HFDK material showing CPE in MK was diluted for subpassage in HFDK cells.

that infectious virus was recovered in MK cells from each passage level of HFDK cells which showed no overt CPE. By the 6th passage the dilution of the original inoculum was greater than $1 \times 10^{-20}$, which rules out the possibility that infectious virus was a residual carry-over.

\subsection{Subcultivation of HFDK Cells Infected with Type B2 Coxsackieviruses}

The next step was to determine whether HFDK cells infected with group B2 coxsackieviruses could be subcultivated, whether the division rate and life span 
would be comparable to that of uninfected cultures, and whether production of infectious virus and antigen demonstrable by FA staining would continue during subcultivation. The three virus strains (Ohio, Lincoln and V1-013) purified by 3 terminal dilution passages in BS-C-1 cells were inoculated into 29 oz. bottle cultures of HFDK cells at a concentration of $5 \times 10^{4}$ infectious doses of virus per culture bottle. Growth medium was fortified MEM with 10 per cent FBS. Controls consisted of 2 uninoculated bottle cultures of HFDK cells and 2 HFDK cultures inoculated with uninfected BS-C-1 cell culture material. After 3 days the cells were dispersed in trypsin and subcultivated at a 2 for 1 split. Initially, subcultivations were made at 3 day intervals. As the division rate slowed down and the total number of recovered cells decreased, the cells were seeded into smaller bottles (29 oz., $16 \mathrm{oz} ., 8 \mathrm{oz}, 4 \mathrm{oz}$.) so that contact inhibition would be reached within $2-4$ days (1). During the terminal subcultivations, cells were left in the bottles for 15 days. The experiment was terminated when the total number of dead cells exceeded the viable cells.

Cells inoculated with either Ohio or Lincoln virus strains yielded infectious virus only up to the second subcultivation, and showed no antigen by FA staining. On the other hand, in Table 2 it is seen that HFDK cells infected with the V1.013

Table 2. Recovery and Identification of Type B2 Coxsackievirus Strain V1-013 after Continuous Passage of Infected HFDK Cells

\begin{tabular}{|c|c|c|c|c|}
\hline $\begin{array}{l}\text { HFDK sub- } \\
\text { eultivation } \\
\text { number }\end{array}$ & Virus passage history & $\begin{array}{l}\text { Indirect FA tests } \\
\text { No. pos. eells/no. } \\
\text { fields examined }\end{array}$ & $\operatorname{TClD}_{50} / \mathrm{mll}^{2}$ & $\begin{array}{l}\text { Neutraliza- } \\
\text { tion test for } \\
\text { identifica- } \\
\text { tion }\end{array}$ \\
\hline 18 & $\mathrm{MK}_{9}, \mathrm{BS}-\mathrm{C}-1_{3}, \mathrm{HFDK}_{2}$ & $\mathrm{ND}^{b}$ & $10^{-4.7}$ & $+c$ \\
\hline 19 & $\mathrm{MK}_{9}, \mathrm{BS}-\mathrm{C}-1_{3}, \mathrm{HFDK}_{3}$ & ND & $10^{-6.5}$ & + \\
\hline 20 & $\mathrm{MK}_{9}, \mathrm{BS}-\mathrm{C}-1_{3}, \mathrm{HFDK}_{4}$ & $104 / 30^{d}$ & ND & $\mathrm{ND}$ \\
\hline 21 & $\mathrm{MK}_{9}, \mathrm{BS}-\mathrm{C}-1_{3}, \mathrm{HFDK}_{5}$ & $\mathrm{ND}$ & $10^{-5.5}$ & $\frac{1}{1}$ \\
\hline $22-29$ & $\mathrm{MK}_{9}, \mathrm{BS}-\mathrm{C}-1_{3}, \mathrm{HFDK}_{6-13}$ & $15-110 / 30$ & $10^{-5.2}-10^{-5.9}$ & + \\
\hline 32 & $\mathrm{MK}_{9}, \mathrm{BS}-\mathrm{C}-1_{3}, \mathrm{HFDK}_{16}$ & $1 / 30$ & $10^{-5.2}$ & + \\
\hline 35 & $\mathrm{MK}_{9}, \mathrm{BS}-\mathrm{C}-1_{3}, \mathrm{HFDK}_{19}$ & $6 / 30$ & ND & $\mathrm{ND}$ \\
\hline 38 & $\mathrm{MK}_{9}, \mathrm{BS}-\mathrm{C}-1_{3}, \mathrm{HFDK}_{22}$ & $5 / 30$ & $10^{-4.0}$ & + \\
\hline
\end{tabular}

a Titrated in BS-C-1 cells.

b Not done.

c Metabolic inhibition test, virus identified as coxsackievirus type B 2 .

d Each field contained approximately 80 cells.

strain produced both infectious virus, in the absence of an overt CPE, and viral antigen demonstrable by FA staining through 22 subcultivations of the cells. The virus recovered from the cultures was identified as coxsackievirus type B2 and after 21 passages in HFDK cells the virus still produced plaques of the same size (2-3 $\mathrm{mm}$ in diameter) as those produced by the original inoculum and also by the prototype and field strains.

Figure 1 compares the cell counts, over the course of subcultivation, of control HFDK cultures and cultures inoculated with the 3 strains of coxsackievirus type 
B2. The experiments were begun with HFDK cells at the 17 th passage level. The control cultures could be subcultivated through a total of 47 transfers. This is in keeping with HAYFLrok's observation that human fetal diploid cells have a life span of approximately 50 transfers (9). However, cells infected with Lincoln or Ohio virus strains could be subcultured for only 37 transfers and cells infected with V1-013 virus for 41 transfers. Even though infectious virus and antigen were not demonstrable in cells inoculated with the Ohio and Lincoln strains, the life span of the cells was shortened. The cells inoculated with V1-013 virus produced both infectious virus and antigen demonstrable by FA staining, but a cytopathic effect was not observed.

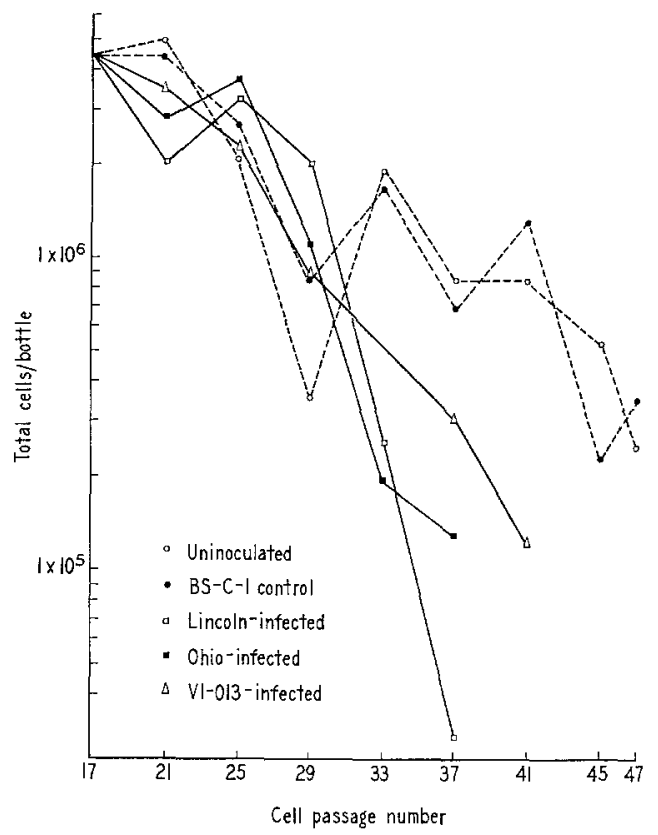

Fig. 1. Cell counts of control and infected HFDK cells. The broken lines represent curves for control cells and the solid lines represent curves for infected cells

\section{Discussion}

The present knowledge regarding enterovirus carrier cultures was obtained by studying the action of viruses in stable cell lines (HeLa) having an infinite life span $(2-4,6,7,13,20)$. Our studies were directed to carrier cultures of type B2 coxsackievirus in human fetal diploid cell strains having a limited life span. The V1-013 strain of coxsackievirus type B2 caused a persistent infection in HFDK cells in which infectious virus and antigen demonstrable by FA staining were produced but a cytopathic effect was not seen. It is possible that infected cells constituted only a small portion of the total cell population and that these cells underwent degeneration without the whole culture showing an overt CPE.

Other workers have reported the necessity of "normal" human serum or serum containing specific viral antibodies for the maintenance of HeLa cell carrier cul- 
tures of polioviruses or coxsackievirus types B3, B5, or A9 $(2-4,6,7,20)$. However, human serum or antiserum was not required for maintenance of HFDK carrier cultures of V1-013 strain of coxsackievirus type B 2, nor was the establishment of carrier cultures dependent on frequent changes of medium. Virus was produced without overt CPE in cultures maintained for 14 days on maintenance medium. The concentration of fetal bovine serum did not appear to be critical, as carrier cultures were established in the presence of 2 per cent FBS in blind passage studies and in 10 per cent FBS when infected cells were subjected to continuous passage. When fetal bovine serum was used in the medium on carrier cultures of HeLa cells infected with other enteroviruses, cytopathic degeneration occurred $(2-4,6,7,20)$. This was not the case in our test system. Carrier cultures were established in both MEM and "fortified" MEM containing twice the concentration of vitamins and amino acids.

Neither the other field strain (Lincoln) nor the prototype (Ohio) strain of coxsackievirus type B2 that we studied was able to establish a sustained infection in HFDK cells. Limited studies on the multiplication of these strains in HFDK cells derived from different embryos were done and, again, apparentinfection could not be established. The ability of $\mathrm{B} 2$ coxsackievirus field strains such as V1-013 to replicate in HFDK cells may be an unusual property.

The Ohio and Lincoln strains could not be shown to establish a persistent infection in HFDK cells with the production of infectious virus or viral antigen demonstrable by FA staining, but cell strains infected with these viruses showed a reduced life span as compared to uninfected control cultures. Although the significance of these findings cannot be firmly established, the fact that all three virus inoculated strains showed a shorter life span than the two uninoculated strains established from the same material and carried in parallel suggests a virusmediated effect. It would be of interest to attempt to demonstrate the possible presence of viral nucleic acid, or virus-specific antigens detectable by other methods. Attempts were made to use the mixed hemadsorption technic (8) to demonstrate virus-specific antigen in HFDK cells inoculated with coxsackievirus type B2. The test detected an antigen present only in infected cells but absent in uninfected cells; however, a great deal of cross-reactivity was seen with heterotypic coxsackieviruses and also with other major groups of viruses. The failure of uninfected cells to react suggests that the antigen might be viral or virusmediated, but the extensive crossing with viruses from other major groups is puzzling.

\section{Acknowledgments}

The authors are indebted to Mrs. Helen H. Ho and Mr. Tak T. Shinomoto for assistance provided during the course of these studies, and to Dr. Wilbur W. Ackermann for reviewing the manuscript.

\section{References}

1. ABERCRombte, M.: Contact-dependent behavior of normal cells and the possible significance of surface changes in virus-induced transformation. Cold Spr. Harb. Symp. quant. Biol. 27, 427-431 (1962).

2. Ackermann, W.W.: Mechanisms of persistent and masked infections in tissue culture. Ann. N.Y. Acad. Sci, 67, 392-402 (1957). 
3. ACKERmann, W. W.: Certain factors governing the persistence of poliovirus in tissue culture. Symposium on Latency and Masking in Viral and Rickettsial Infections. (D. WaLker, R. Hanson, and A. Evans, eds.) pp. 169-175. Minneapolis: Burgess, 1958.

4. AckermanN, W. W., and H. Kurtz: Observations concerning a persisting infec. tion of HeLa cells with poliomyelitis virus. J. exp. Med. 102, 555 565 (1955).

5. CommitтeE on Enterovirus: Classification of human enteroviruses. Virology 16, 501-504 (1962).

6. Crowelr, R. L.: Specific viral interference in HeLa cell cultures chronically infected with coxsackievirus B 5 virus. J. Bact. 86, 517-526 (1963).

7. Croweli, R. L., and J. T. Sxverton: The mammalian cell-virus relationship. VI. Sustained infection of $\mathrm{H} \ominus \mathrm{La}$ cells by coxsackie B 3 virus and effect on superinfection. J. exp. Med. 113, $419-435$ (1961).

8. Espmark, A., and A. Fagraeus: Detection of antigens in tissue culture with the aid of mixed hemadsorption. Acta path. microbiol. scand., Suppl. 154, 258-262 $(1962)$.

9. HAyFLIok, L.: The limited in vitro lifetime of human diploid cell strains. Exp. Cell Res. 37, 614-635 (1965).

10. LwoFf, A.: Lysogeny. Bact. Rev. 17, 269-337 (1953).

11. McSwiggan, D. A., and R. GEORGE: A comparison of two cell culture systems for the primary isolation of enteric viruses. Bull. Wrld Hlth Org. 43, 295-300 (1970).

12. Metaick, J. L., and H. A. Whnner : Enteroviruses. In: Diagnostic Procedures for Viral and Rickettsial Infections. 4th Ed., (E. H. LeNNETTE and N. J. ScHMidt, eds.) p. 529. New York, N.Y.: Amer. publ. Hlth Ass. Inc., 1969.

13. Padsa, P.: Poliovirus-carrying lines of HeLa cells: Their establishment and sensitivity to viruses. Acta microbiol. Acad. Sci. hung. 8, 329-332 (1961).

14. Purcell, R. H., and R. M. Chanock: Mycoplasmas of Human Origin. In: Diagnostic Procedures for Viral and Rickettsial Infections. 4th Ed., (E. H. LENNETTE and N. J. Schmot, eds.) p. 786. New York, N.Y.: Amer. publ. Hlth Ass. Inc., 1969.

15. Rigas, J. L., P. C. Loh, and W. C. Eveland: A simple fractionation method for preparation of fluorescein-labeled gamma globulin. Proc. Soc. exp. Biol. (N.Y.) 105, 655-658 (1961).

16. Sснмidt, N. J.: Tissue Culture Technics for Diagnostic Virology. In: Diagnostic Procedures for Viral and Rickettsial Infections. 4th Ed., (E. H. LenNette and N. J. Sснмidт, eds.) p. 79. New York, N.Y.: Amer. publ. Hlth Ass. Inc., 1969.

17. Sснмidт, N. J.: Tissue culture in the laboratory diagnosis of viral infections. Amer. J. clin. Path. 57, 820-828 (1972).

18. Schmot, N. J., R. W. Guenther, and E. H. Lennette: Typing of ECHO virus isolates by immune serum pools. The "intersecting serum scheme". J. Immunol. $87,623-626(1961)$.

19. Schmidt, N.J., H. H. Ho, and E. H. Lennetre: Comparative sensitivity of human fetal diploid kidney cell strains and monkey kidney cell cultures for isolation of certain human viruses. Amer. J. clin. Path. 43, 297-301 (1965).

20. TAKEMOTO, K. K., and K. HABEx: Virus-cell relationship in a carrier culture of HeLa cells and coxsackie A 9 virus. Virology 7, 29-44 (1959).

21. The, T. H., and T. E. W. Feutkamp : Conjugation of fluorescein isothiocyanate to antibodies. II. A reproducible method. Immunology 18, 875 881 (1970).

22. TrLtFajová, J.: The sensitivity of the human diploid cell strain WI-38 to different viruses. J. Hyg. Epidem. (Praha) 14, 413-419 (1970).

23. WAtKer, D. L.: The viral carrier state in animal cell cultures. Progr. med. Virol. 6, 111-148 (1964).

Authors' address: E. H. Lennetre, M.D., Chief, Viral and Rickettsial Disease Laboratory, California State Department of Public Health, 2151 Berkeley Way, Berkeley, CA 94704, U.S.A. 